\title{
Growth and Mortality of Coral Transplants (Pocillopora damicornis) along a Range of Sediment Influence in Maui, Hawai ${ }^{i}{ }^{1}$
}

\author{
Gregory A. Piniak ${ }^{2,3,4}$ and Eric K. Brown $n^{5,6}$
}

\begin{abstract}
Fragments of the lace coral Pocillopora damicornis (Linnaeus, 1758) were transplanted to four sites on the south-central coast of Maui, Hawai ${ }^{i}$, to examine coral growth over a range of expected sediment influence. Corals remained in situ for 11 months and were recovered seasonally for growth measurements using the buoyant weight technique. Average sediment trap accumulation rates ranged from 11 to $490 \mathrm{mg} \mathrm{cm}^{-2}$ day $^{-1}$ and were greater at the waveexposed reef site than at the protected harbor sites. Coral growth was highest at the donor site and was higher in the summer than in the winter. A stepwise linear regression found significant effects of sediment trap accumulation and light on growth rates, but the partial correlation coefficients suggest that these factors may be only secondary controls on growth. This study did not show a clear link between coral growth and sediment load. This result may be due, in part, to covariation of sediment load with wave exposure and the inability of trap accumulation rates to integrate all sediment effects (e.g., turbidity) that can affect coral growth.
\end{abstract}

Twenty-Two PERCENT of the world's coral reefs are threatened by sediment and landbased pollution (Bryant et al. 1998). In Hawaici, the total sediment runoff from agricultural, industrial, ranching, and urban sources exceeds 1 million tons per year (Gulko et al. 2000). With so much material moving through the system, coral reefs in

${ }^{1}$ This study was funded by a U.S. Geological Survey Mendenhall Postdoctoral Research Fellowship to G.A.P. Manuscript accepted 1 March 2007.

${ }^{2}$ Corresponding author.

${ }^{3}$ U.S. Geological Survey Pacific Science Center, 400 Natural Bridges Drive, Santa Cruz, California 95060.

${ }^{4}$ Current contact information: NOAA Center for Coastal Fisheries and Habitat Research, 101 Pivers Island Road, Beaufort, North Carolina 28516 (e-mail: greg.piniak@noaa.gov).

${ }_{5}^{5}$ Hawai'i Institute of Marine Biology, P.O. Box 1346, Kāne'ohe, Hawai'i 96744.

${ }^{6}$ Current contact information: Kalaupapa National Historic Park, P.O. Box 2222, Kalaupapa, Hawai'i 96742 (e-mail: Eric_Brown@nps.gov).

Pacific Science (2008), vol. 62, no. 1:39-55

(C) 2008 by University of Hawaici Press

All rights reserved
Hawai'i can be vulnerable to sediment stress. High wave energy might be more important than anthropogenic factors in structuring coral reef communities on exposed coastal reefs in some parts of Hawai'i (Grigg 1983), but sedimentation could pose a particular threat in populated areas such as Maui and O'ahu (Gulko et al. 2000), in protected embayments (Dollar and Grigg 2004), or in areas where land use patterns contribute to erosion. Some coral communities are naturally exposed to considerable sediment transport and deposition, but anthropogenic activities can alter the amount, timing, and type (terrigenous versus carbonate) of sediment delivered to the system.

One common approach to test the impact of water quality on coral health has been to measure the growth rate of coral transplants (Davies 1990). In recent years this technique has been employed to study the effects of sewage (McKenna et al. 2001), aquaculture waste (Bongiorni et al. 2003a,b), sedimentation (Te 2001), and thermal stress (Smith and Birkeland 2003). Resource managers often need to predict the impact of a stress, even when pre-stress baseline data are not 
available; comparing growth of coral transplants at impacted and control sites can provide a sublethal stress indicator. Growth can be measured in numerous ways (see review by Buddemeier and Kinzie 1976). A common growth index is linear extension, but the most common methods in the literature (alizarin staining, $\mathrm{x}$-rays) require destructive sampling. Buoyant weight (Jokiel et al. 1978) is another common technique and has the advantage of being noninvasive and allowing repeated measurements of the same colony over time.

This study was part of a U.S. Geological Survey project on the geologic and oceanographic processes that affect coral reef systems in Hawai'i (Ogston et al. 2004, Storlazzi et al. 2004, 2005, 2006, Bothner et al. 2006, Presto et al. 2006, Stamski and Field 2006). The objective of this study was to describe the effects of sediment on the growth of scleractinian corals in situ. Fragments of the lace coral Pocillopora damicornis Linnaeus, 1758 , were transplanted to four sites for a period of 11 months. Transplant sites included an exposed carbonate beach and a protected embayment with terrestrial sediment input. Growth rates were measured seasonally using the buoyant weight technique. The specific hypothesis tested was that coral growth would decrease at higher sediment loads.

\section{MATERIALS AND METHODS}

Pocillopora damicornis was used for this study because its branching morphology lends itself well to fragmentation and transplantation, it is present at all of the study sites, and much is known about its energetics and responses to environmental stress. Using clones for a transplant study minimizes genetic variability and increases confidence in attributing differences in growth to environmental variables. However, the $P$. damicornis colonies at the study sites were too small $(10-15 \mathrm{~cm}$ diameter) to furnish a sufficient number of clonal fragments from a single colony. Instead a single donor site was selected on the assumption that corals from a single donor site that are in close proximity are genotypically similar (e.g., Hunter 1993).

\section{Study Sites}

Four transplant sites (depth 2 to $2.5 \mathrm{~m}$ ) were established with a range of sediment loading and wave exposure along the south-central coast of Maui, Hawai'i (Figure 1, Table 1). Three sites were located in Mā'alaea Harbor. Surface sediment on the harbor bottom ranges from fine mud at the west end of the harbor to coarser carbonate sediment near the harbor entrance. The East mole site was established near the harbor entrance where coral cover is the highest (30-40\% [Jokiel and Brown 1998]). The Boat dock site was near a drainage culvert at the west end of the harbor. The Triangle reef site was in the middle of the harbor, where a remnant reef gives way to small rocky outcrops within a sandy plain. The Mā‘alaea sites are protected from the prevailing southerly swell by two breakwaters built in the 1950s (Jokiel and Brown 1998). In contrast, the site just offshore of Sugar Beach was a low-relief reef pavement with sparse coral cover. Surface sediment was largely marine carbonate, and the site was subject to heavy seasonal south swell. Pocillopora damicornis was the local dominant coral at the Triangle, which served as the donor site for the study. Pocillopora damicornis was also present in low abundance at the Boat dock and was rare at the East mole site and Sugar Beach.

\section{Coral Transplants}

In August 2003, P. damicornis colonies were collected from Triangle reef and brought to the laboratory at the Maui Ocean Center. Individual branches $(3-4 \mathrm{~cm}$ tall) were trimmed from the colonies, attached to a polyvinyl chloride (PVC) mount using epoxy (Splash Zone) (average weight of mount plus epoxy $2.985 \mathrm{~g}$ ), and randomly labeled with colorcoded numbered tags (FTF-69, Floy Tag, Inc.). Transplants were weighed to the nearest $0.001 \mathrm{~g}$ on a balance (Sartorius CP-153) using the buoyant weight method (Jokiel et al. 1978). After a 2-day recovery period in an indoor, flow-through seawater system

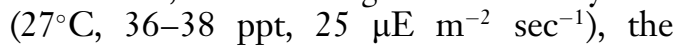
transplants were deployed at the four experi- 


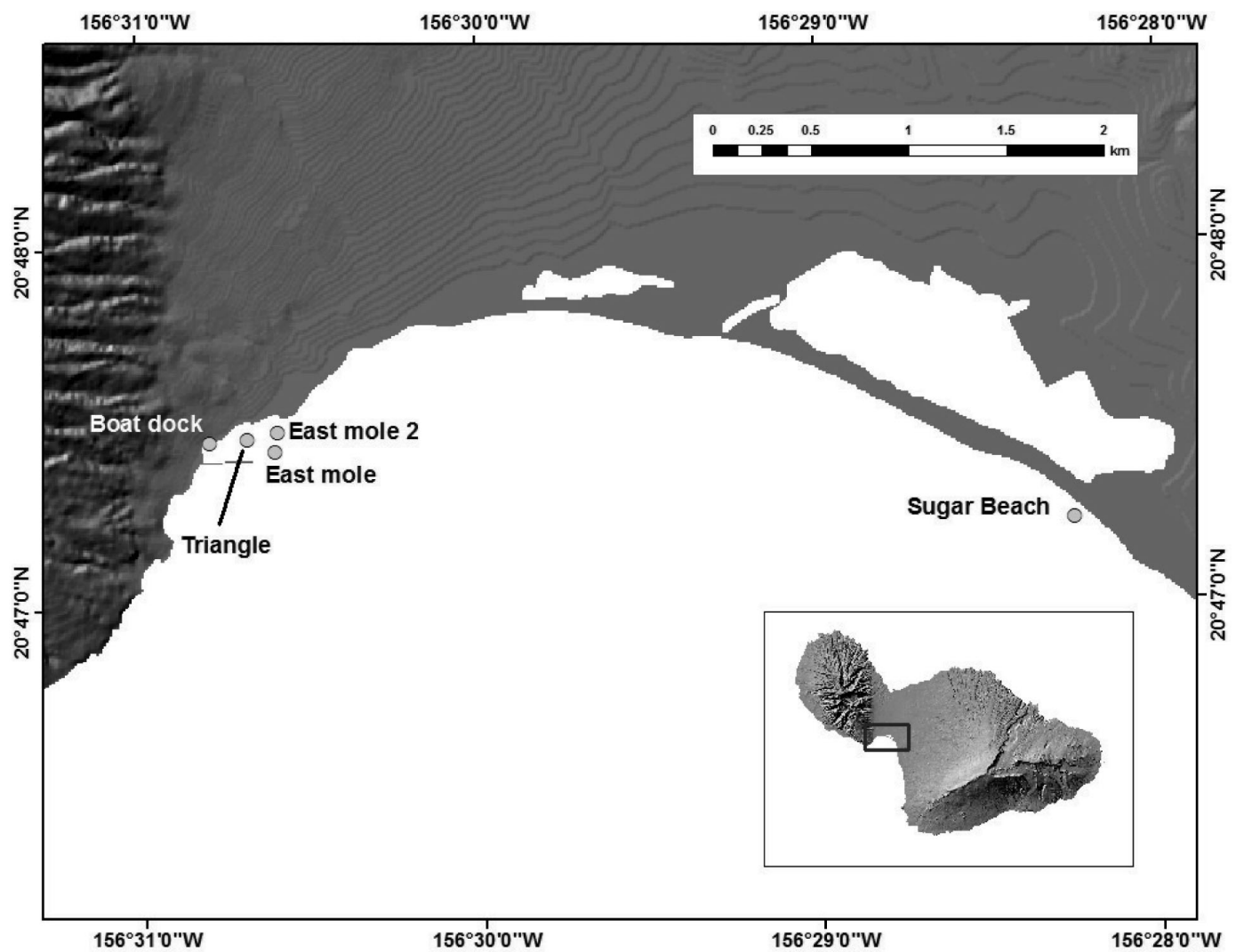

FIgUre 1. Location of coral transplant sites in Maui.

mental sites. At each site, three cinder blocks (Figure 2) were placed 2-3 m apart, in sandy areas between coral heads. Each cinder block (19.4 by 19.4 by $39.7 \mathrm{~cm}$ ) had two parallel PVC racks of four corals each (total $n=24$ corals per site). A sediment trap (see following section) was attached to each cinder block. The cinder blocks were left uncaged to minimize hydrodynamic artifacts and changes in light regime due to biofouling.

TABLE 1

Coral Transplant Sites on Maui, Hawaici

\begin{tabular}{lcccc}
\hline \hline Site & Latitude & Longitude & Depth $(\mathrm{m})$ & Wave Exposure \\
\hline Sugar Beach & $20^{\circ} 47.222^{\prime} \mathrm{N}$ & $156^{\circ} 28.250^{\prime} \mathrm{W}$ & 2 & Open \\
Mā'alaea Boat dock & $20^{\circ} 47.460^{\prime} \mathrm{N}$ & $156^{\circ} 30.800^{\prime} \mathrm{W}$ & 2 & Protected \\
Mā'alaea Triangle & $20^{\circ} 47.467^{\prime} \mathrm{N}$ & $156^{\circ} 30.688^{\prime} \mathrm{W}$ & 2 & Protected \\
Mā'alaea East mole & $20^{\circ} 47.433^{\prime} \mathrm{N}$ & $156^{\circ} 30.607^{\prime} \mathrm{W}$ & 2 & Protected \\
Mā'alaea East mole 2 & $20^{\circ} 47.488^{\prime} \mathrm{N}$ & $156^{\circ} 30.599^{\prime} \mathrm{W}$ & 2.5 & Protected \\
\hline
\end{tabular}

Note: The Mā'alaea Triangle was the donor site for all transplants. In February 2004 the location of the East mole site was changed due to fish predation. 


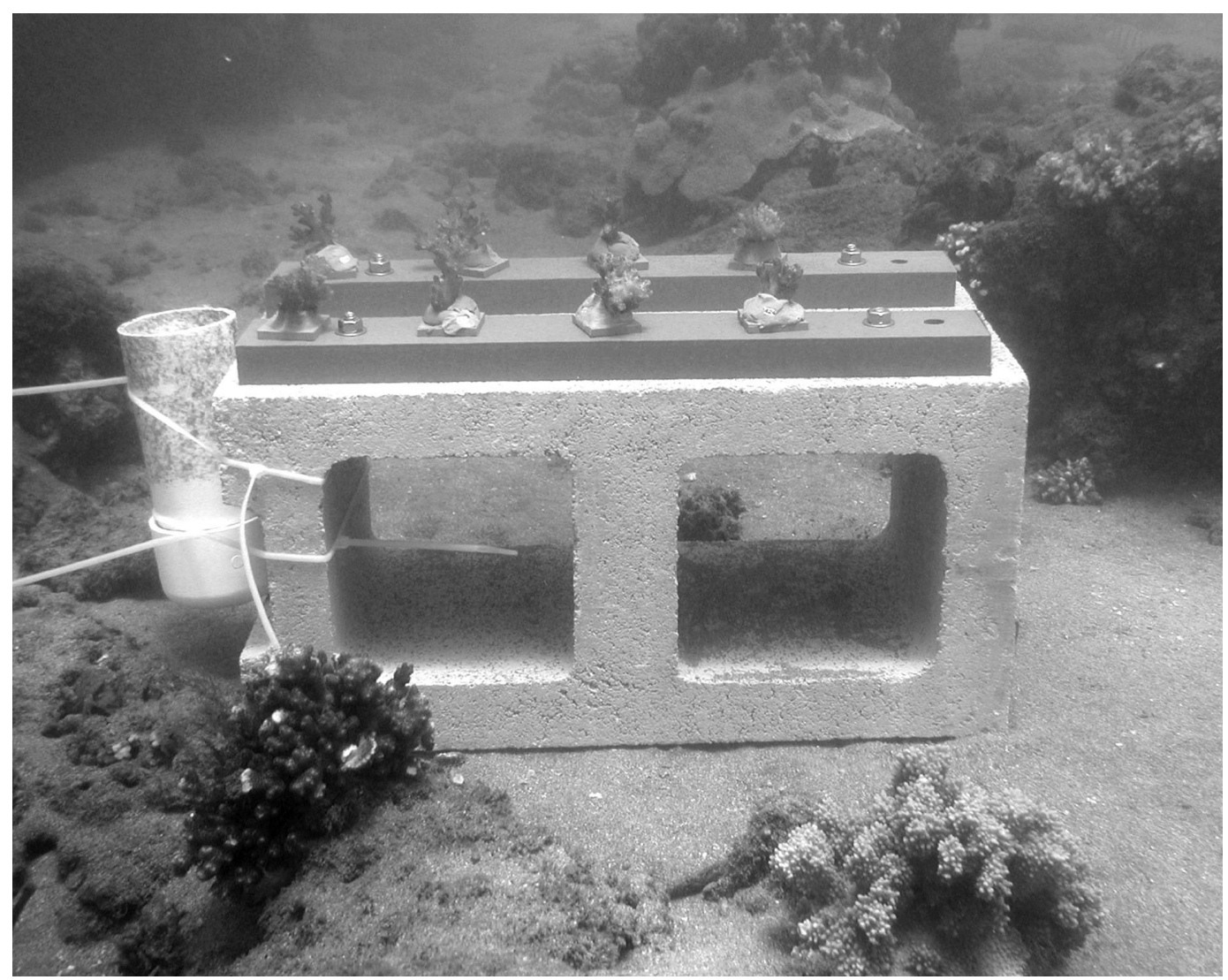

Figure 2. Coral transplants at the Triangle reef donor site in Mā‘alaea Harbor. Each cinder block is 39.7 by 19.4 by $19.4 \mathrm{~cm}$.

Corals were retrieved from the field every $3-$ 4 months. In the laboratory, colony condition was noted (healthy $=100 \%$ live tissue; partial mortality = live tissue but less than $100 \%$; dead $=$ no live tissue). Biofouling organisms on the transplant platform were removed, and corals were weighed using the buoyant weight technique. Coral growth rates were reported as daily mass change $\left(\mathrm{mg}\right.$ days $\left.^{-1}\right)$ and percentage growth $\left(\%\right.$ day $^{-1}$, corrected for the weight of the PVC stand and epoxy). Only corals with live tissue (i.e., the healthy and partial mortality classes) were used for growth rate analyses.

After weighing, corals were returned to their specific transplant sites. When transplants suffered high mortality at a given site (storms, fish predation, etc.), all corals for that site were replaced by new $P$. damicornis transplants from the donor site. The Mā'alaea East mole site was relocated farther inside the harbor in February 2004 in an effort to avoid high mortality from fish predation at the original site.

\section{Physical Environment}

The relative amount of sediment accumulation at each site was measured using sediment accumulation tubes. The tubes consisted of PVC pipe $5.1 \mathrm{~cm}$ diameter by $15.2 \mathrm{~cm}$ height, with an endcap on the bottom (E.K.B., 1999, unpubl. data). A tube was tied with cable to each cinder block so that its opening was $1-2 \mathrm{~cm}$ above the top of the cinder block (Figure 2). Traps did not include baffles or 
other preventive measures to mitigate bioturbation. All sediment accumulation tubes were changed approximately monthly. The contents of the traps were rinsed with freshwater, filtered, and dried to a constant weight (mg $\mathrm{cm}^{-2}$ day $^{-1}$ ). Representative sediment samples were analyzed for grain size and percentage carbonate using methods standardized by the Western Coastal and Marine Geology team of the U.S. Geological Survey (modified from Carver 1971 and Folk 1974). Sediment particles 63-2,000 $\mu \mathrm{m}$ were analyzed using $2-\mathrm{m}$ settling tubes (modified from Theide et al. [1976]). Carbon and carbonate analyses were conducted with UIC Coulometrics systems CM 150 and CM 5200 .

Water temperature at each site was measured at hourly intervals using a data logger (Onset HOBO Water Temp Pro). Light levels on the seafloor were measured hourly with a light intensity data logger (HOBO StowAway) in a clear underwater housing. Four deployments were made that corresponded to each growth period. Light intensity plots within each 75-day sampling interval (growth period) showed a decline in daily maximum intensity after 30-40 days, which was attributed to biofouling on the housing. Consequently, only daily average irradiance for the first 30 days was used for each of the four growth periods. Variation in seasonal irradiance was simplified using a standardized day length: December to February, 11 hours; March to May and September to November, 12 hours; June to August, 13 hours. Average daily irradiance was estimated as the average hourly rate times the number of daylight hours (Anthony and Connolly 2004). Logger data were converted from $\log \left(\operatorname{lumens} \mathrm{m}^{-2}\right)$ to photosynthetically active radiation (PAR) ( $\mu \mathrm{m}$ quanta $\mathrm{m}^{-2} \mathrm{sec}^{-1}$ ) by calibrating the HOBO loggers against an underwater light sensor (LiCor Li192SA) (equation $\mathrm{PAR}=3.4136 * \mathrm{e}^{1.4898 * \text { intensity }}$ ).

\section{Statistical Analysis}

Statistical analysis was conducted using Statistica 6.1 (StatSoft 2001). Data were tested for equal variances using Levene's test, and normality assumptions were tested using a Kolmogorov-Smirnoff test for goodness of fit (Sokal and Rohlf 1995). Sediment trap accumulation rates, light meter data, and certain subsets of the growth data met parametric assumptions after log transformation. All other data that failed to meet assumptions after transformation were analyzed using nonparametric statistics. Effects of time and location on physical data (sediment, light, temperature), growth, and mortality were tested with analyses of variance (ANOVAs) or nonparametric equivalents, using time and location as categorical factors. Effects of physical data on growth and mortality were tested using similar analyses.

\section{RESULTS}

\section{Sediment Trap Data}

Average accumulation rates for the cinder block sediment traps at all sites ranged from 11 to $490 \mathrm{mg} \mathrm{cm}^{-2}$ day $^{-1}$ (Figure 3). Because a two-way analysis was unbalanced (due to loss of traps, etc.), the effects of time and site were clearer when tested separately. Trap accumulation rates differed significantly among sites (Figure 3; $F=21.8 ; \mathrm{df}=3,94$; $P<.001)$. Sugar Beach had higher sediment accumulation rates than the Mā'alaea Harbor sites (Tukey HSD post hoc comparisons, $P<.001)$. The Boat dock had the highest trap accumulation rates in the harbor (East mole, $P=.006$; Triangle, $P=.033$ ). Sediment accumulation rates varied significantly over time at all four sites, but effects were not consistent from site to site. The weakest effects were at Sugar Beach $(F=3.3$; df $=$ $7,13 ; P=.031)$ and at the Boat dock $(F=3.4 ; \quad \mathrm{df}=8,16 ; \quad P=.014)$. However, Tukey HSD post hoc tests found no significant differences over time at either site. Temporal effects were stronger at the East mole $(F=74.6 ; \mathrm{df}=8,16 ; P<.001)$ and Triangle $(F=122.1 ; \mathrm{df}=8,16 ; P<.001)$ sites, where sediment accumulation was highest in February, March, June, and July (Figure 3).

A representative subset of the sediment samples was analyzed for grain size and composition (Table 2). Sediment at the East mole 

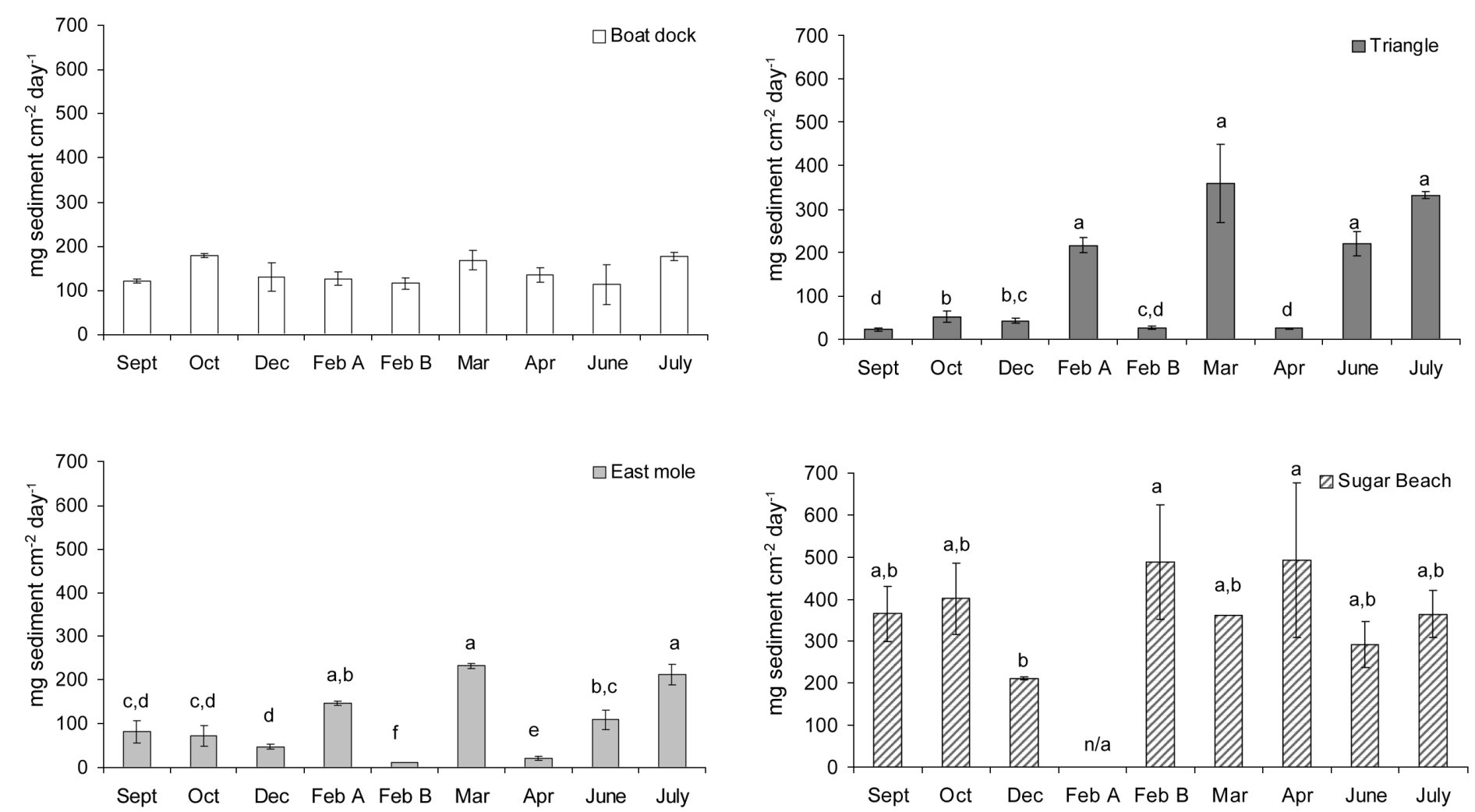

FIGURE 3. Sediment trap data for the study sites. Deployment periods were September (26 August to 28 September 2003), October (28 September to 18 October 2003), December (18 October to 7 December 2003), February A (7 December 2003 to 2 February 2004), February B (2 February to 22 February 2004$)$, March (22 February to 20 March 2004), April (20 March to 18 April 2004), June (18 April to 10 June 2004), and July (10 June to 18 July 2004$)$. No data exist in February A for Sugar Beach. For each panel, lower-case letters indicate groupings that are significantly different as determined by Tukey HSD post hoc comparisons $(P<.05)$. Error bars are standard deviation. 
TABLE 2

Composition of Selected Sediment Samples in Mā‘alaea Harbor

\begin{tabular}{lccc}
\hline \hline Parameter & East mole & Boat dock & Triangle \\
\hline September 2003 & & & \\
\% Gravel $(>2 \mathrm{~mm})$ & $4.9 \pm 4.2$ & $0.0 \pm 0.0$ & $0.0 \pm 0.0$ \\
\% Sand $(0.62-2 \mathrm{~mm})$ & $48.8 \pm 13.5$ & $7.5 \pm 2.0$ & $62.8 \pm 8.3$ \\
\% Silt $(0.04-0.62 \mathrm{~mm})$ & $41.9 \pm 1.6$ & $86.0 \pm 1.2$ & $33.6 \pm 7.5$ \\
\% Clay $(<0.04 \mathrm{~mm})$ & $4.4 \pm 1.6$ & $0.02 \pm 0.01$ & $3.7 \pm 0.8$ \\
Mean grain size $(\varphi)$ & $0.13 \pm 0.3$ & $1.82 \pm 0.05$ & $0.10 \pm 0.02$ \\
Sorting $(\varphi)$ & $3.25 \pm 0.63$ & $21.7 \pm 0.1$ & $2.54 \pm 0.35$ \\
\% Carbonate & $53.0 \pm 8.7$ & $1.2 \pm 1.5$ & $50.4 \pm 6.8$ \\
February 2004 & $1.6 \pm 1.4$ & $8.9 \pm 4.6$ & $0.0 \pm 0.0$ \\
\% Gravel $(>2 \mathrm{~mm})$ & $62.8 \pm 5.3$ & $82.1 \pm 4.3$ & $85.7 \pm 4.6$ \\
\% Sand $(0.62-2 \mathrm{~mm})$ & $30.7 \pm 4.3$ & $7.8 \pm 1.9$ & $12.8 \pm 4.1$ \\
\% Silt $(0.04-0.62 \mathrm{~mm})$ & $5.0 \pm 3.2$ & $0.02 \pm 0.01$ & $1.5 \pm 0.5$ \\
\% Clay $(<0.04 \mathrm{~mm})$ & $0.10 \pm 0.40$ & $1.93 \pm 0.08$ & $0.14 \pm 0.01$ \\
Mean grain size $(\varphi)$ & $2.24 \pm 0.72$ & $22.5 \pm 0.7$ & $1.30 \pm 0.09$ \\
Sorting $(\varphi)$ & $49.3 \pm 3.7$ & & $66.5 \pm 0.7$ \\
\% Carbonate & & & \\
\hline
\end{tabular}

Note: Data are postacidified percentage composition for each size fraction, and carbonate composition is for the bulk sample. Data are averages \pm SD for the three cinder blocks at each site.

and Triangle was predominantly carbonate sand and gravel. In contrast, $90 \%$ of the sediment at the Boat dock was silt and clay that was primarily terrigenous in origin (only $\sim 22 \%$ carbonates, less than half the content of the other two sites). Mean grain size was smallest at the Boat dock, and sediments at all three sites were poorly or very poorly sorted. There was no correlation between mean grain size and sediment trap accumulation rate $(r=0.07, P=.802)$.

\section{Temperature and Light}

Light levels and water temperatures were reported only for the Mā'alaea Harbor sites because meters at Sugar Beach were disturbed during strong wave events. Light (Figure 4) varied significantly with both site $(F=240.8$; $\mathrm{df}=2,351 ; P<.001)$ and time $(F=4.5$, $\mathrm{df}=3,350 ; P=.004)$. Average light intensity was higher at the East mole than at the Triangle (Dunnet post hoc test, $P=.005$ ), which in turn was higher than at the Boat dock $(P<.001)$. Winter light levels (February to April) were lower than those from August to October $(P=.004)$. There was also a significant but weak negative correlation be- tween sediment trap data and light levels (both data sets $\log$ transformed, $r=-0.33$, $P<.001)$.

Average daily water temperatures in Mā'alaea Harbor ranged from 23.8 to $27.7^{\circ} \mathrm{C}$ (Figure $5 A$; no data were available for the Boat dock and East mole sites for April-July due to errors with the temperature loggers). Temperatures differed seasonally (KruskalWallis, $\mathrm{df}=3, N=764, H=337.0, P<$ $.001)$; water was significantly warmer in August-October and significantly colder in February-April (multiple comparison of mean ranks, $P<.001)$. Temperature was not significantly different between sites (KruskalWallis, $\mathrm{df}=2, N=764, H=4.3, P=.117$ ). Diel variability in water temperature was approximated by calculating the variance in the hourly temperatures used for each daily temperature average (Figure $5 B$ ). Variance was greatest near the harbor mouth and lowest at the Boat dock (Kruskal-Wallis, $\mathrm{df}=2$, $N=764, H=145.0, P<.001)$. There was also a significant seasonal effect on temperature variance (Kruskal-Wallis, $\mathrm{df}=3, N=$ $764, H=65.6, P<.001)$, which was highest during the August to October period and lowest from February to April. 


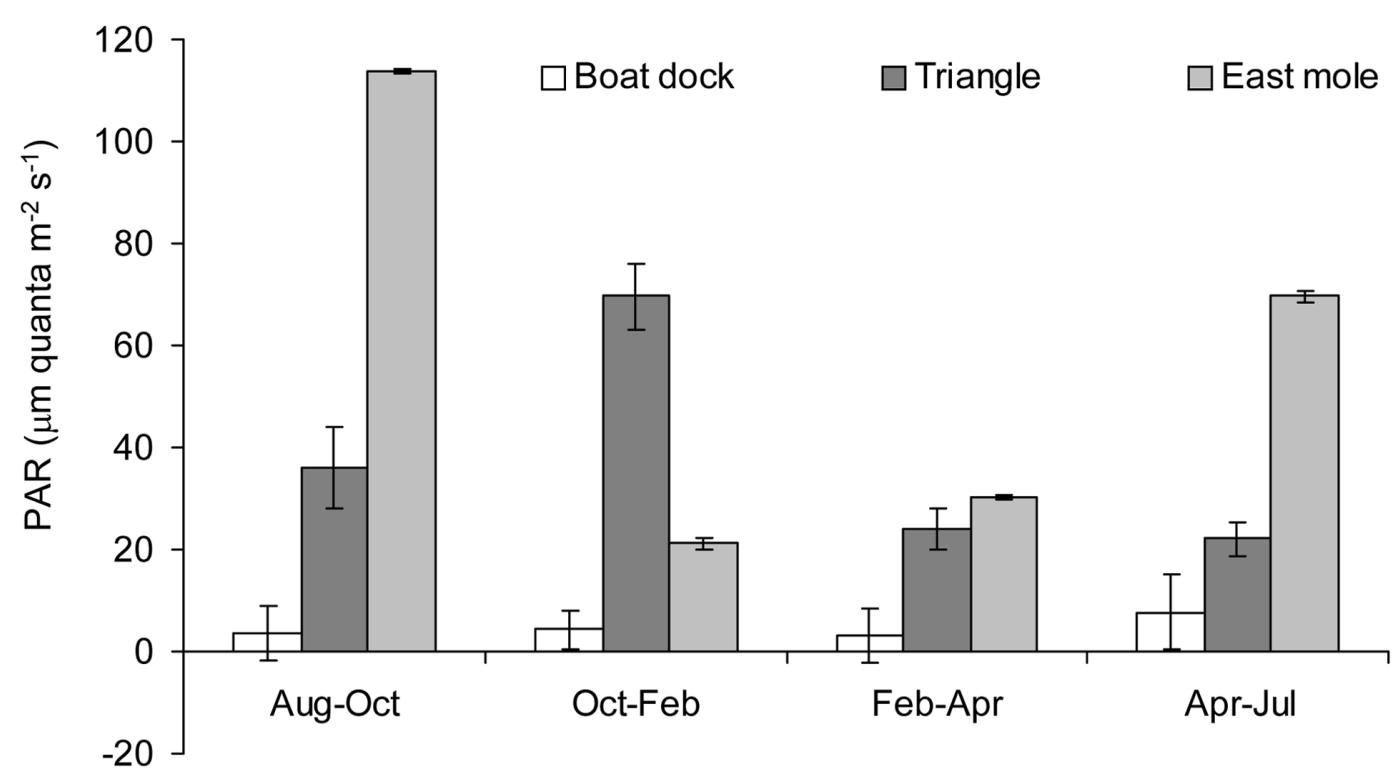

FIgURE 4. Average hourly daytime light levels at the study sites in Mā'alaea Harbor. PAR, photosynthetically active radiation.

\section{Coral Growth and Mortality}

Growth rates were analyzed for corals with live tissue only, in units of overall mass gained (Figure $6 \mathrm{~A}$ ) and change relative to the overall mass of the transplant (e.g., percent change, Figure 6B). Negative growth rates were possible; the most commonly observed case was tissue regrowth after a loss of skeletal mass (breakage, predation, etc.). Growth rates were significantly different among sites (Kruskal-Wallis, $\mathrm{df}=3$, $N=240$; overall mass $H=153.3, P<.001$; percentage change $H=1,452.7, P<.001$ ). When daily mass changes were weighted for the length of each growing "season," the Triangle had the highest average growth (52.0 $\mathrm{mg}$ day $^{-1}$ or $3.1 \%$ day $^{-1}$ ). The Boat dock averaged a slight positive growth over the course of the year $\left(3.1 \mathrm{mg}\right.$ day $^{-1}$ or $0.3 \%$ day $\left.^{-1}\right)$, and the East mole site lost weight on average $\left(-16.5 \mathrm{mg} \mathrm{day}{ }^{-1}\right.$ or $-1.1 \%$ day $\left.^{-1}\right)$. However growth was not constant over the course of the year (Figure 6). Percent change did not vary seasonally (Kruskal-
Wallis, $\mathrm{df}=3, N=240, H=6.7, P=.082$ ), but there was a significant effect of season on overall mass gained $(H=11.7, P=.008)$. When sites were tested individually, seasonal growth patterns were not consistent among sites. For example, August-October showed the lowest growth at the Boat dock (post hoc multiple comparison of mean ranks, $P<.002)$, but February-April showed the lowest growth at the Triangle $(P<.002)$.

For all sites combined, there was a slight positive correlation between growth rates and sediment trap accumulation $(r=0.14$, $P=.03)$. Light and temperature data were not collected at the Sugar Beach site, and the East mole had poor survivorship (see following paragraph). Therefore, effects of environmental parameters on growth rates were tested using the Boat dock and Triangle sites. A stepwise linear regression for growth rates at these two sites $(F=60.7 ; \mathrm{df}=3,151$; $P<.001)$ produced significant but weak regression coefficients for $\log$ photosynthetically active radiation $(b=0.772, P<.001$, $\left.R^{2}=0.110\right)$ and $\log$ sediment trap accumula- 
A.

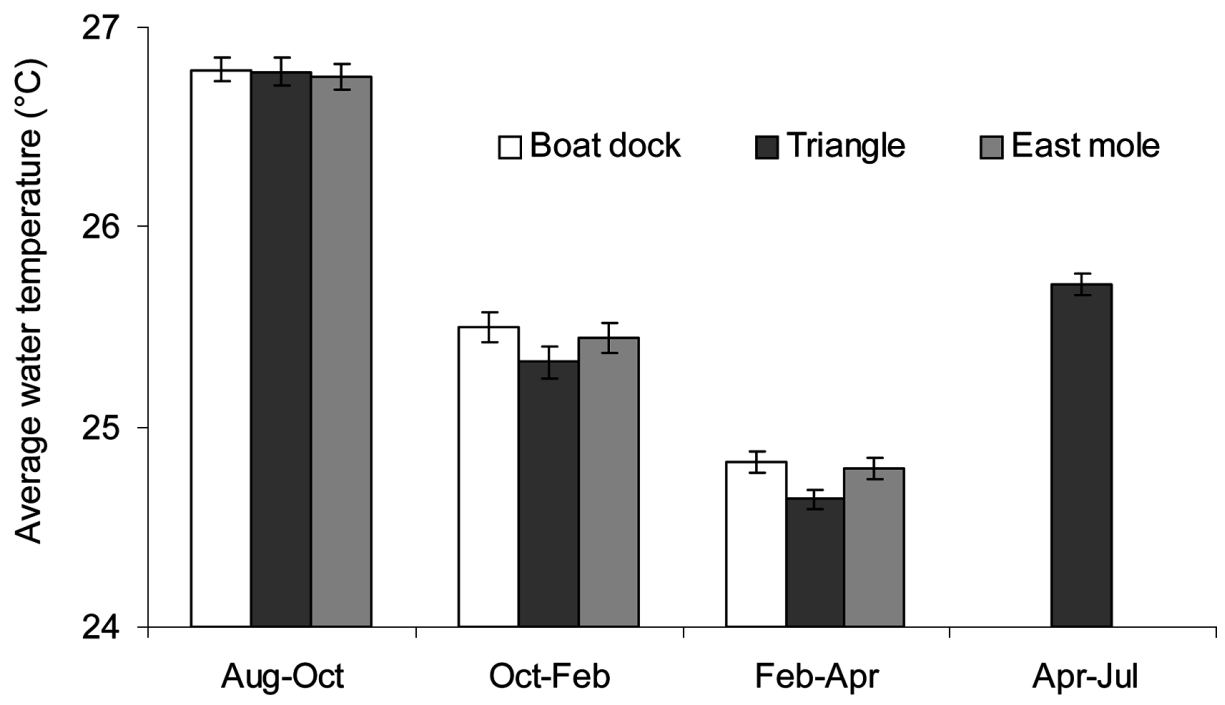

B.

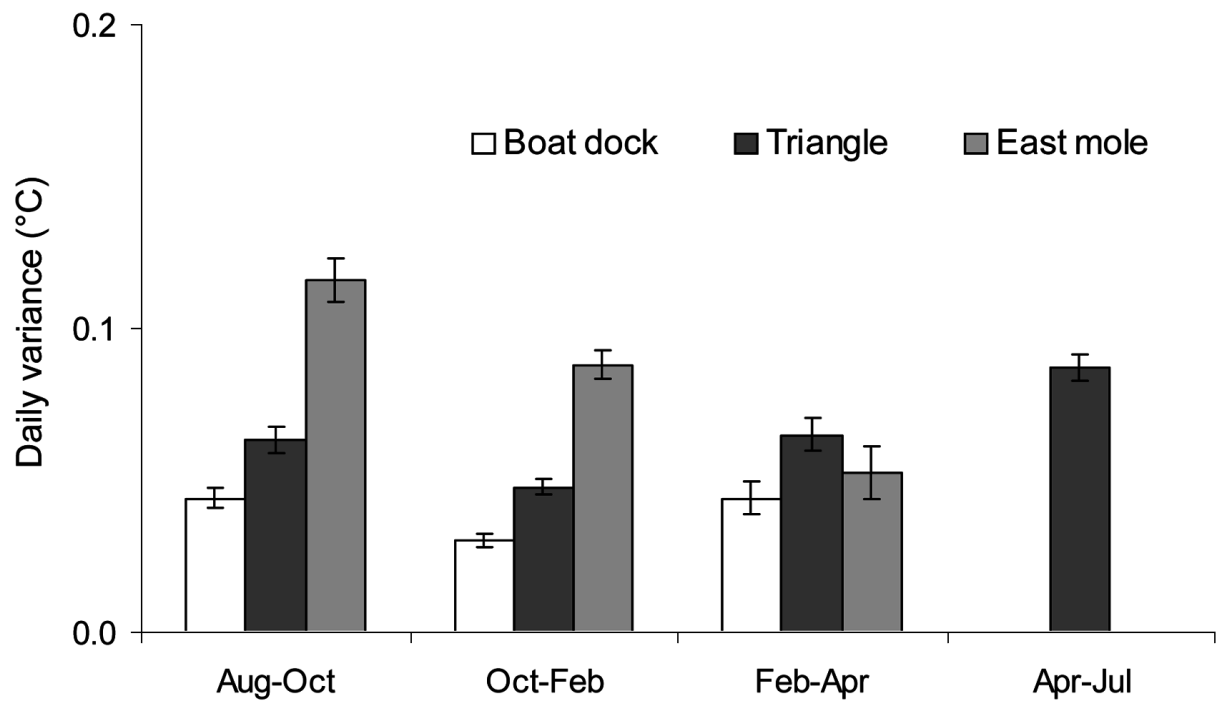

Figure 5. Average daily temperature $(A)$ and temperature variance $(B)$ at the study sites in Mā'alaea Harbor. 
A.

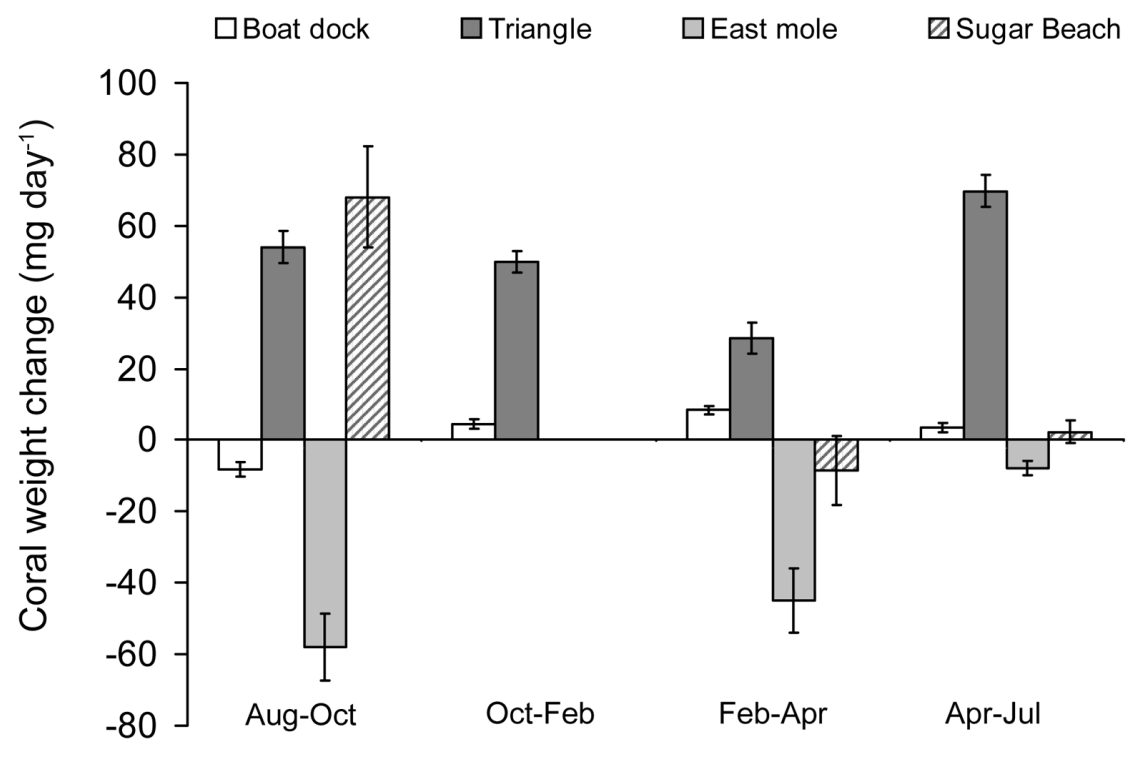

B.

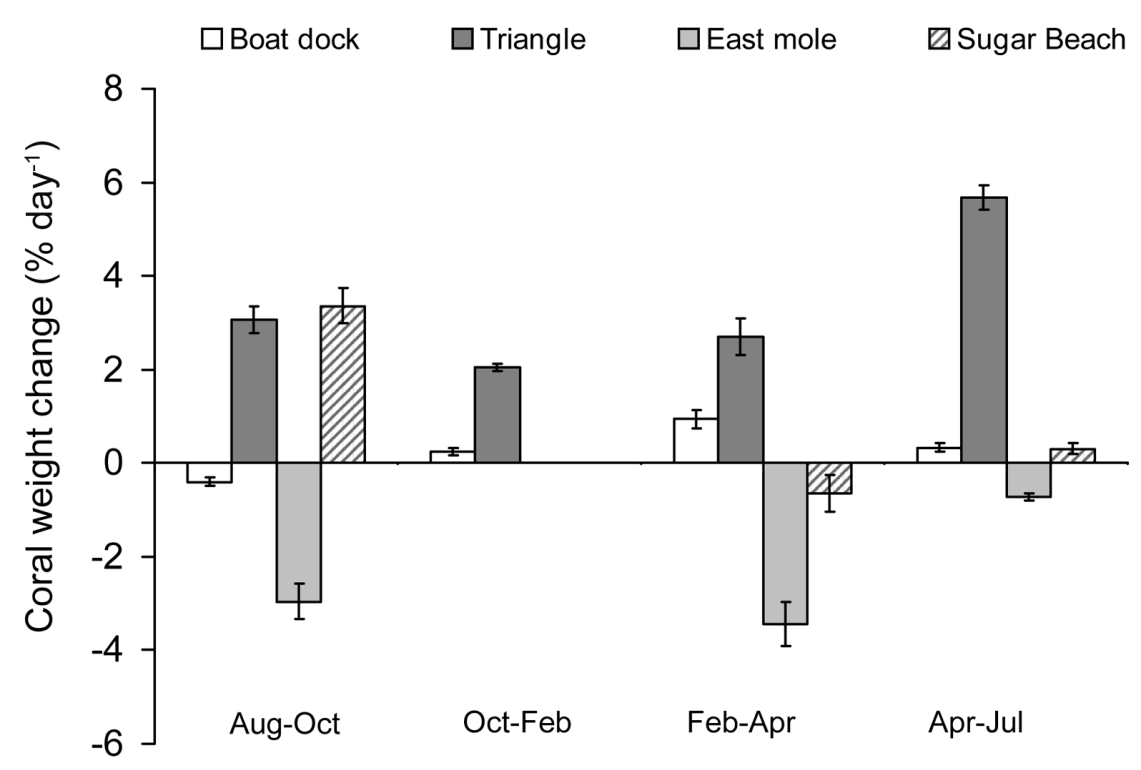

FIGURE 6. Daily growth rates of Pocillopora damicornis transplants at the study sites, in terms of overall mass gain $(A)$ and percent of colony mass $(B)$. 
TABLE 3

Percentage Survivorship and Mortality for Coral Transplants in South-Central Maui

\begin{tabular}{llcccc}
\hline \hline Site & Season & \% Healthy & \% Partial Mortality & \% Dead & Mortality Source \\
\hline \multirow{2}{*}{ Boat dock } & Aug.-Oct. & 87.5 & 8.3 & 4.2 & Burial \\
& Oct.-Feb. & 37.8 & 29.2 & 33.0 & Burial \\
& Feb.-Apr. & 41.7 & 58.3 & 0.0 & Burial \\
\multirow{5}{*}{ Triangle } & Apr.-July & 12.5 & 45.8 & 41.7 & Burial \\
& Aug.-Oct. & 100.0 & 0.0 & 0.0 & \\
& Oct.-Feb. & 100.0 & 0.0 & 0.0 & \\
\multirow{5}{*}{ East mole } & Feb.-Apr. & 100.0 & 0.0 & 0.0 & Burial \\
& Apr-July & 87.5 & 0.0 & 12.5 & Fish \\
& Aug.-Oct. & 0.0 & 29.2 & 70.8 & Fish, algae \\
& Oct.-Feb. & 0.0 & 50.0 & 50.0 & Fish, algae \\
& Feb.-Apr. & 0.0 & 45.8 & 54.2 & Fish, algae \\
& Apr.-July & 0.0 & 16.7 & 83.3 & Storms \\
& Aug.-Oct. & 100.0 & 0.0 & 0.0 & Storms \\
& Oct.-Feb. & 0.0 & 0.0 & 62.5 & Storms \\
\hline
\end{tabular}

tion $\left(b=0.161, P=.023, R^{2}=0.387\right)$. The regression coefficient for water temperature was not significant $(b=0.126, P=.062)$.

During the experiment high partial mortality and transplant death was observed at Sugar Beach and the East mole sites (Table 3). Mortality rates were tested statistically by determining the combined mortality (death plus partial mortality) at each sampling interval for each cinder block at each site. A nonparametric two-way ANOVA (Scheirer-RayHare extension of Kruskal-Wallis) showed that mortality varied among sites $(\mathrm{df}=3$, $H=10.1, .025>P>.01$ ), but season and site-season interactions were not significant. An analysis of covariance (ANCOVA) was used to test the possible contribution of sediment trap accumulation rates to mortality. The ANCOVA used arcsin-square root transformed combined mortality as the response variable, with site as the categorical predictor and log-transformed sediment trap accumulation as the continuous predictor. Site effects were significant $(F=25.2 ; \mathrm{df}=$ $3,43 ; P<.001)$, but trap accumulation rates were not $(F=0.1 ; \mathrm{df}=1,43 ; P=.79)$. Mortality at the Sugar Beach and the East mole sites commonly occurred from confounding sources (predation, storm damage). However, repeating the ANCOVA using only the Boat dock and Triangle sites gave similar results (site $F=28.7$; df $=1,21 ; P<.001$; sediment $F=0.240 ; \mathrm{df}=1,21 ; P=.63)$.

\section{DISCUSSION}

Study sites were selected to represent the range of sediment influence to which $P_{0-}$ cillopora damicornis is exposed in Maui's nearshore environments. Sediment loads were determined using sediment trap accumulation rates, a technique that has been criticized for its limited temporal resolution (Thomas and Ridd 2005). Nevertheless, it is appropriate here because seasonal coral growth rates integrate effects over a greater time scale than the sediment sampling interval ( monthly). Sediment traps have well-defined hydrodynamic limitations and cannot capture all potential sediment dynamics relevant to corals (e.g., turbidity, abrasion, burial). Trap efficiency increases with the aspect ratio (height: diameter) of the traps, and Gardner (1980) reported maximum collection efficiency in flows $<15 \mathrm{~cm} \mathrm{sec}^{-1}$ for traps with an aspect ratio of $2-3$. The aspect ratio for traps in this study was $\sim 3$-this is appropriate for the low to moderate flow environments in Mā'alaea Harbor, but sediment resuspension by wave action at Sugar Beach could affect 
collection rates. Given these caveats, trap accumulation rates given here should be interpreted as the relative rather than absolute sediment impact at a site.

Sediment trap accumulation rates in southcentral Maui showed substantial variability, with average accumulation rates ranging from 11 to $490 \mathrm{mg} \mathrm{cm}{ }^{-2}$ day $^{-1}$. This is comparable with other sediment trap data for the main Hawaiian Islands. Along the West Maui coastline, sediment accumulation rates range from 6 to $510 \mathrm{mg} \mathrm{cm}$ day $^{-1}$ (E.K.B., unpubl. data). Sediment traps on the Moloka'i forereef collected an average of $50 \mathrm{mg} \mathrm{cm}{ }^{-2}$ day $^{-1}$ but reached up to 1,800 $\mathrm{mg} \mathrm{cm}{ }^{-2}$ day $^{-1}$ during storm events (Bothner et al. 2006). Sediment trap rates were 1 to $12 \mathrm{mg} \mathrm{cm}{ }^{-2}$ day $^{-1}$ in Kāne'ohe Bay in $\mathrm{O}^{\prime}$ ahu and 2 to $250 \mathrm{mg} \mathrm{cm}{ }^{-2}$ day $^{-1}$ at more wave-exposed sites at Kawaihae, Hawai' $i$ (Te 2001). Higher water motion has been shown to be correlated with trap collection rates due to resuspension of the sediment in the water column (Kozerski 1994). Higher water motion appears to partially explain the variable accumulation rates observed in this study, because sediment traps at waveexposed Sugar Beach collected significantly more sediment than traps within protected Mā'alaea Harbor.

Sediment accumulating at the Boat dock was mostly terrigenous silt and clay with low carbonate content (Table 2); fine sediment accumulates at the Boat dock but is transported out of the system by the higher wave energy at the Triangle and East mole sites (which had predominantly coarser marine carbonate sediment). The Boat dock may also receive higher terrestrial input, because it is adjacent to two of the three drainage pipes that enter Mā'alaea Harbor. However, severe rainfall events were not apparent in the Boat dock sediment traps but instead were correlated with sediment pulses at the Triangle and East mole sites observed in subsequent trap collections. Dry periods did not decrease sediment accumulation rates at the Boat dock or any other site.

This study considered the relationship between growth and three physical factors: sediment trap accumulation, light level, and water temperature. Growth rates in $M \bar{a}^{\mathrm{c}}$ alaea Harbor were highest in the summer (Figure $6 A$ ), when both light (Figure 4) and temperature (Figure $5 A$ ) were at their maximum. Although these factors covary, they both have positive effects on growth. For example, light enhances calcification in $P$. damicornis (Roth et al. 1982). Skeletal growth in $P$. damicornis in Hawai $i$ is greatest at about $26-27^{\circ} \mathrm{C}$ (Jokiel and Coles 1977), and average water temperatures in Mā'alaea Harbor were within that range from April to October (Figure $5 A$ ). The lack of spatial variability in water temperature within the harbor suggested that the relationship between temperature and growth was consistent among all harbor sites (Figure $5 A$ ) and why temperature was not significant in the stepwise regression for coral growth.

Distinguishing between the effects of light and sediment on coral growth in situ is complicated, because the two factors can covary via turbidity. In this study, photosynthetically active radiation was the first factor added in the forward stepwise regression, whereas sediment explained a greater proportion of the variance in $P$. damicornis growth. Both effects were positive and significant but relatively weak. Turbidity was not directly measured but can be inferred from the photosynthetically active radiation and sediment trap data. The Boat dock and Triangle are close together $(\sim 200 \mathrm{~m})$. Light at the water surface was likely to be similar, yet there were considerable differences in light at the seafloor despite similar depths. Trap accumulation rates were not appreciably different for the two sites (yearly average $19.1 \mathrm{mg} \mathrm{cm}^{-2}$ day $^{-1}$ for Triangle reef, $17.9 \mathrm{mg} \mathrm{cm}^{-2}$ day $^{-1}$ for the Boat dock), but sediment size at the Boat dock is appreciably smaller (Table 2) along with lower light levels (Figure 4). These results suggest that higher turbidity levels existed at the Boat dock due to suspension of the finer-grained sediments, and the consequent reduction in photosynthetically active radiation could have accounted for the lower growth rates observed at that site.

It is also possible that reduction in light and increase in turbidity combined to shift $P$. damicornis energetics. Sediment load de- 
creases coral photosynthesis while increasing respiratory losses and mucus production (Riegl and Branch 1995), and tissue could be lost due to abrasion. These processes all reduce the amount of energy available for coral growth. However, some corals can also derive an energetic benefit from sediment (Rosenfeld et al. 1999, Mills et al. 2004). P. damicornis has been shown to feed readily on sediment (Anthony 1999) and may be able to compensate for low photosynthesis:respiration ratios at elevated turbidity by increasing heterotrophic consumption (Anthony 2000). These effects should be highest for the muddy sediment at the Boat dock, because fine sediments are likely to be both less abrasive and more nutritious (Anthony and Larcombe 2002). Any possible energetic benefits of sediment were likely insufficient to offset the low light at the Boat dock, because growth and survivorship were much lower than at the Triangle reef site.

The predominant view in the literature is that sediment negatively impacts coral reefs. This is likely to be the general case, and terrigenous sediment runoff has been implicated in coral damage observed in Honolua Bay (Dollar and Grigg 2004) and on the south coast of Moloka'i (Jokiel et al. 2004). These results appear to be inconsistent with our study, in which we did not observe a clear negative effect of sediment on growth of $P$. damicornis. However, the results of our study are consistent with other examples from Hawai' $i$ in which chronic sediment stress had little effect on coral physiology. Turbidity of up to 1.0 nephelometric turbidity unit (NTU) was significantly and positively correlated with growth of Montipora verrucosa and $P$. damicornis in Kāne'ohe Bay (Coles and Ruddy 1995) (P. damicornis growth was also significantly and positively correlated with sediment trap rates). A later study in the same area found no relationship between sediment trap accumulation and either coral growth or mortality for Porites compressa and M. verrucosa (Te 2001), and Maragos (1972) found that $M$. verrucosa growth was actually highest at intermediate levels of turbidity and light extinction. It may be that chronic, adverse effects of sediment and turbidity on corals are more likely to operate at the community or population level instead of the physiological level (Anthony 2006). Sediment clearly causes population-level mortality (Nugues and Roberts 2003), reduces diversity (Brown et al. 1990), and inhibits coral recruitment (Gilmour 1999), yet some corals can physiologically adapt to sediment stress. Corals in highly turbid environments can maintain elevated metabolic indices, including lipid levels (Anthony 2006) and RNA/ DNA ratios (a proxy for protein synthesis [Bak and Meesters 2002]).

Alternatively, it is possible that the weak positive relationship between sediment and growth observed in this study would differ if a growth metric other than mass change were used. For example, coral tissue growth may be more responsive to resource variation than skeletal growth, because positive skeletal growth can be maintained even when tissue growth is negative (Anthony et al. 2002). Along a suggested sediment gradient in the Gulf of Mexico, linear extension was inversely correlated with skeletal density and calcification rates, suggesting that corals under sediment stress generate higher linear extension rates by reducing skeletal density (Carricart-Ganivet and Merino 2001). Linear extension of Montastraea annularis in Puerto Rico was negatively correlated with sediment trap data and percentage terrigenous sediment (Torres 2001). This response can be interpreted as a mechanism for corals to avoid being smothered by high sedimentation rates. In contrast, Edinger et al. (2000) found that linear extension was negatively correlated with "downward sediment flux" (a misleading term when applied to sediment trap data). Still other studies found no correlation between linear extension and sediment load (Brown et al. 1990, Barnes and Lough 1999).

The relationship between sediment and growth in our study was further confounded by mortality from external factors at Sugar Beach and the East mole sites. Wave energy is an important factor controlling coral reef distribution and zonation in Hawai'i (Dollar 1982, Storlazzi et al. 2005), because storm events cause mortality from breakage, scour, and abrasion (Grigg 1998). When wave 
energy is low during late summer and early fall, corals at the Sugar Beach site gained just as much mass as corals at Triangle reef (Figure 6). This was not a function of linear extension; instead coral skeletons at Sugar Beach had a higher density than those at the Triangle (G.A.P., unpubl. data). This is a typical response of corals to increased hydrodynamic force (Scoffin et al. 1992). However, winter waves at Sugar Beach did cause coral mortality when the cinder blocks turned over or moved out of their original sand holes.

The other site with high mortality was the East mole site in $\mathrm{Ma}^{-}$alaea Harbor. Fish grazing can exclude $P$. damicornis from sites that would otherwise be suitable (Neudecker 1979, Cox 1994), and grazing pressure can influence the outcomes of transplant studies (Coles and Ruddy 1995). Corallivorous fishes comprised $<1 \%$ of the fish community in Mā'alaea Harbor (Jokiel and Brown 1998), so it was assumed that the transplants would not be subjected to substantial grazing pressure. However transplants in the first two weighing intervals (August-October and October-February) suffered very high grazing mortality at the East mole site, so in February 2004 the site was relocated $100 \mathrm{~m}$ north to an area just off the edge of the reef flat. Pufferfish (Arotbron bispidus and A. meleagris) were occasionally observed at the new site, but corals already at the site showed little evidence of fish grazing. This new site, however, was closer to shore, and the reef flat is potentially impacted by septic tank leakage from coastal development (Jokiel and Brown 1998). Groundwater discharge could have caused algal blooms of Ulva fasciata and $U$. reticulata observed at the site. Although $P$. damicornis may be less sensitive than other coral species to spatial competition with algae (Tanner 1995), some transplants at the site were killed by algae dislodged by water motion that became entangled with the transplants as the algae were being advected out of the harbor.

\section{CONCLUSIONS}

The relationship between sediment and coral growth can be complicated, particularly for field studies in which environmental effects that covary with sediment (light, wave exposure, etc.) cannot be isolated. The intent of this study was to measure coral growth along a range of sediment influence to test the hypothesis that coral growth would decrease with increasing sediment load, which this study did not observe. Instead there was a significant positive relationship between growth and sediment trap data, but the strength of the correlation $\left(R^{2}=0.387\right)$ suggests that factors other than sediment accumulation were the primary controls of coral growth. The relationship between coral growth and sediment may depend on how growth is measured, how sediment load is quantified, and the intervals at which both are measured. Sediment traps are commonly used in field studies but do not adequately capture the full range of sediment effects on coral growth processes (e.g., turbidity, abrasion, heterotrophic particle capture, etc.).

\section{ACKNOWLEDGMENTS}

We thank the Maui Ocean Center for their invaluable logistic support, the Hawai'i Department of Aquatic Resources for granting the scientific permits, and Charlene Tetlak and Mike Torresan at the U.S. Geological Survey for the sediment analyses. The manuscript was improved by comments from Mike Field, Caroline Rogers, Kimberly Yates, and three anonymous reviewers. The use of trademark names does not imply U.S Geological Survey endorsement of products.

\section{Literature Cited}

Anthony, K. R. N. 1999. Coral suspension feeding on fine particulate matter. J. Exp. Mar. Biol. Ecol. 232:85-106.

—. 2000. Enhanced particle-feeding capacity of corals on turbid reefs (Great Barrier Reef, Australia). Coral Reefs 19:59-67.

- 2006. Enhanced energy status of corals on coastal, high-turbidity reefs. Mar. Ecol. Prog. Ser. 319:111-116.

Anthony, K. R. N., and S. R. Connolly. 2004. Environmental limits to growth: Physiological niche boundaries of corals along 
turbidity-light gradients. Oecologia (Berl.) 141:373-384.

Anthony, K. R. N., S. R. Connolly, and B. L. Willis. 2002. Comparative analysis of energy allocation to tissue and skeletal growth in corals. Limnol. Oceanogr. 47:1417-1429.

Anthony, K. R. N., and P. Larcombe. 2002. Coral reefs in turbid waters: Sedimentinduced stresses in corals and likely mechanisms of adaptation. Pages 239-244 in Proc. 9th Int. Coral Reef Symp., Bali. Vol. 1. Indonesian Institute of Sciences and State Ministry for Environment, Jakarta, Indonesia.

Bak, R. P. M., and E. H. Meesters. 2002. Acclimatization/adaptation of coral reefs in a marginal environment. Pages 265-271 in Proc. 9th Int. Coral Reef Symp., Bali. Vol. 1. Indonesian Institute of Sciences and State Ministry for Environment, Jakarta, Indonesia.

Barnes, D. J., and J. M. Lough. 1999. Porites growth characteristics in a changed environment: Misimia Island, Papua New Guinea. Coral Reefs 18:213-218.

Bongiorni, L., S. Shafir, D. Angel, and B. Rinkevich. 2003a. Survival, growth and gonad development of two hermatypic corals subjected to in situ fish-farm nutrient enrichment. Mar. Ecol. Prog. Ser. 253:137-144.

Bongiorni, L., S. Shafir, and B. Rinkevich. $2003 \mathrm{~b}$. Effects of particulate matter released by a fish farm (Eilat, Red Sea) on survival and growth of Stylophora pistillata coral nubbins. Mar. Pollut. Bull. 46:11201124.

Bothner, M. H., R. L. Reynolds, M. A. Casso, C. D. Storlazzi, and M. E. Field. 2006. Quantity, composition, and source of sediment collected in sediment traps along the fringing coral reef off Molokai, Hawaii. Mar. Pollut. Bull. 52:1034-1047.

Brown, B. E., M. D. A. LeTissier, T. P. Scoffin, and A. W. Tudhope. 1990. Evaluation of the environmental impact of dredging on intertidal coral reefs at Ko Phuket, Thailand, using ecological and physiological parameters. Mar. Ecol. Prog. Ser. 65:273-281.

Bryant, D., L. Burke, J. McManus, and M.
Spalding. 1998. Reefs at risk: A map-based indicator of threats to the world's coral reefs. World Resources Institute, Washington, D.C.

Buddemeier, R. W., and R. A. Kinzie III. 1976. Coral growth. Oceanogr. Mar. Biol. Annu. Rev. 14:183-225.

Carricart-Ganivet, J. P., and M. Merino. 2001. Growth responses of the reefbuilding coral Montastrea annularis along a gradient of continental influence in the southern Gulf of Mexico. Bull. Mar. Sci. 68:133-146.

Carver, R. E., ed. 1971. Procedures in sedimentary petrology. Wiley Interscience, New York.

Coles, S. L., and L. Ruddy. 1995. Comparison of water quality and reef coral mortality and growth in southeastern Kāne'ohe Bay, O'ahu, Hawai'i, 1990 to 1992, with conditions before sewage diversion. Pac. Sci. 49:247-265.

Cox, E. F. 1994. Resource use by corallivorous butterflyfishes (Family Chaetodontidae) in Hawaii. Bull. Mar. Sci. 54:535545.

Davies, P. S. 1990. A rapid method for assessing growth rates of corals in relation to water pollution. Mar. Pollut. Bull. 21:346-348.

Dollar, S. J. 1982. Wave stress and coral community structure in Hawaii. Coral Reefs $1: 71-81$.

Dollar, S. J., and R. W. Grigg. 2004. Anthropogenic and natural stresses on selected coral reefs in Hawai' $\mathrm{i}$ : A multidecade synthesis of impact and recovery. Pac. Sci. 58:281-304.

Edinger, E. N., G. V. Limmon, J. Jompa, W. Widjatmoko, J. M. Heikoop, and M. J. Risk. 2000. Normal coral growth rates on dying reefs: Are coral growth rates good indicators of reef health? Mar. Pollut. Bull. 40:404-425.

Folk, R. L. 1974. Petrology of sedimentary rocks, University of Texas Geology $370 \mathrm{~K}$, 383L, 383M. Hemphill Publishing Co., Austin, Texas.

Gardner, W. D. 1980. Field assessment of sediment traps. J. Mar. Res. 36:40-52.

Gilmour, J. 1999. Experimental investigation into the effects of suspended sediment on 
fertilization, larval survival and settlement in a scleractinian coral. Mar. Biol. (Berl.) 135:451-462.

Grigg, R. W. 1983. Community structure, succession and development of coral reefs in Hawaii. Mar. Ecol. Prog. Ser. 11:1-14. . 1998. Holocene coral reef accretion in Hawaii: A function of wave exposure and sea level history. Coral Reefs 17:263272.

Gulko, D., J. Maragos, A. Friedlander, C. Hunter, and R. Brainard. 2000. Status of coral reefs in the Hawaiian Archipelago. Pages 219-238 in C. Wilkinson, ed. Status of coral reefs of the world: 2000. Australian Institute of Marine Science, Cape Ferguson, Australia.

Hunter, C. L. 1993. Genotypic variation and clonal structure in coral populations with different disturbance histories. Evolution 47:1213-1228.

Jokiel, P. L., and E. K. Brown. 1998. Coral baseline survey of Mā'alaea harbor for light-draft vessels, island of Maui. http:// cramp.wcc.hawaii.edu/Study_Sites/Maui/ Maalaea/Maalaea_Assessment.

Jokiel, P. L., E. K. Brown, A. Friedlander, S. K. Rodgers, and W. R. Smith. 2004. Hawai'i Coral Reef Assessment and Monitoring Program: Spatial patterns and temporal dynamics in reef coral communities. Pac. Sci. 58:159-174.

Jokiel, P. L., and S. L. Coles. 1977. Effects of temperature on the mortality and growth of Hawaiian reef corals. Mar. Biol. (Berl.) 43:201-208.

Jokiel, P. L., J. E. Maragos, and L. Franzisket. 1978. Coral growth: Buoyant weight technique. Pages 529-541 in Coral reefs: Research methods. UNESCO, Paris.

Kozerski, H. P. 1994. Possibilities and limitations of sediment traps to measure sedimentation and resuspension. Hydrobiologia 284:93-100.

Maragos, J. 1972. A study of the ecology of Hawaiian reef corals. Ph.D. diss., University of Hawai'i at Mānoa, Honolulu.

McKenna, S. A., R. H. Richmond, and G. Roos. 2001. Assessing the effects of sewage on coral reefs: Developing techniques to detect stress before coral mortality. Bull. Mar. Sci. 69:517-523.
Mills, M. M., F. Lipschultz, and K. P. Sebens. 2004. Particulate matter ingestion and associated nitrogen uptake by four species of scleractinian corals. Coral Reefs 23: 311-323.

Neudecker, S. 1979. Effects of grazing and browsing fishes on the zonation of corals in Guam. Ecology 60:666-672.

Nugues, M. M., and C. M. Roberts. 2003. Partial mortality in massive reef corals as an indicator of sediment stress on coral reefs. Mar. Pollut. Bull. 46:314-323.

Ogston, A. S., C. D. Storlazzi, M. E. Field, and M. K. Presto. 2004. Sediment resuspension and transport patterns on a fringing reef flat, Molokai, Hawaii. Coral Reefs 23:559-569.

Presto, M. K., A. S. Ogston, C. D. Storlazzi, and M. E. Field. 2006. Seasonal and spatial variability on the dispersal and transport of suspended sediment on a shallow fringing reef flat, Moloka'i, Hawai'i. Estuarine Coastal Shelf Sci. 67:67-81.

Riegl, B., and G. M. Branch. 1995. Effects of sediment on the energy budgets of four scleractinian (Bourne 1900) and five alcyonacean (Lamouroux 1816) corals. J. Exp. Mar. Biol. Ecol. 186:259-275.

Rosenfeld, M., V. Bresler, and A. Abelson. 1999. Sediment as a possible source of food for corals. Ecol. Lett. 2:345-348.

Roth, A. A., C. D. Clausen, P. Y. Yahiku, V. E. Clausen, and W. W. Cox. 1982. Some effects of light on coral growth. Pac. Sci. 36:65-82.

Scoffin, T. P., A. W. Tudhope, B. E. Brown, H. Chansang, and R. F. Cheeney. 1992. Patterns and possible environmental controls of skeletogenesis of Porites lutea, South Thailand. Coral Reefs 11:1-11.

Smith, L. W., and C. Birkeland. 2003. Managing NPSA's coral reefs in the face of global warming: Research project report for year 1. Hawai'i Cooperative Fishery Unit, Department of Zoology, University of Hawai'i at Mānoa, Honolulu.

Sokal, R. R., and F. J. Rohlf. 1995. Biometry. W. H. Freeman, New York.

Stamski, R. E., and M. E. Field. 2006. Characterization of sediment trapped by macroalgae on a Hawaiian reef flat. Estuarine Coastal Shelf Sci. 66:211-216. 
StatSoft. 2001. Statistica, version 6.1. Tulsa, Oklahoma.

Storlazzi, C. D., E. K. Brown, M. E. Field, K. Rodgers, and P. Jokiel. 2005. A hydrodynamic model to predict wave control on coral breakage and species distribution: Southern Molokai, Hawaii. Coral Reefs 24:43-55.

Storlazzi, C. D., M. A. McManus, J. B. Logan, and B. E. McLaughlin. 2006. Cross-shore velocity shear, eddies and heterogeneity in water column properties over fringing reefs: West Maui, Hawaii. Cont. Shelf Res. 26:401-421.

Storlazzi, C. D., A. S. Ogston, M. H. Bothner, M. E. Field, and M. K. Presto. 2004. Wave- and tidally-driven flow and sediment flux across a fringing coral reef: Southern Molokai, Hawaii. Cont. Shelf Res. 24:1397-1419.

Tanner, J. E. 1995. Competition between scleractinian corals and macroalgae: An ex- perimental investigation of coral growth, survival, and reproduction. J. Exp. Mar. Biol. Ecol. 190:151-168.

Te, F. T. 2001. Responses of Hawaiian scleractinian corals to different levels of terrestrial and carbonate sediment. Ph.D. diss., University of Hawai'i at Mānoa, Honolulu.

Theide, J., T. Chriss, T. M. Clauson, and S. A. Swift. 1976. Settling tubes for size analysis of fine and coarse fractions of oceanic sediment. Oregon State University School of Oceanography, Report 76-8.

Thomas, S., and P. Ridd. 2005. Field assessment of innovative sensor for monitoring of sediment accumulation at inshore coral reefs. Mar. Pollut. Bull. 51: 470-480.

Torres, J. L. 2001. Impacts of sedimentation on the growth rates of Montastrea annularis in Southwest Puerto Rico. Bull. Mar. Sci. 69:631-637. 
